\title{
The Writing and the Doing-about Artistic Research through a Writing Practice
}

\author{
Fredrik Nyberg
}

\begin{abstract}
The article discusses the emergence of artistic research within the discipline Literary Composition at the University of Gothenburg. The text assumes a critical vantage point in its reflections upon the specific circumstances generated by the artistic text and its metacritical dimensions. These dimensions, inherent to the literary composition, are illustrated by two concrete poetic examples which are contextualised by two historical sections. The first engages in a more general discussion, while the second is comprised of a reading of the three dissertations currently available within Literary Composition at the University of Gothenburg. On the whole, the article localises a research method and praxis which increasingly takes place through rather than about literary composition.
\end{abstract}

\section{Introduction}

The Swedish philosopher Jonna Hjerström Lappalainen writes, "When we are to reflect on our practice we turn to theory. What then happens is that we are caught in the gaze of theory, theory's distinctions and theory's limitations. We see practice as a voiceless feminine phenomenon to be seduced or conquered by theory."1 The following text is conceived to address various attempts that, together, strive to arrive at a form of representation which can disrupt and bring to an end this in many ways problematic conquest. Perhaps a series of exchanges between practice (also regarded as a thinking) and theory (also seen as a doing) can then instead arise. A situation where one no longer knows who conquers whom. Or, perhaps even better, a comparable situation wherein metaphors of militarism can be retired.

Does the luminosity of language cast everyone in the same light?

1 Jonna Hjertström Lappalainen, "Att reflektera över det som ännu inte sagts," in: Magnus William-Olsson, ed., Methodos. Konstens kunskap, kunskapens konst. Stockholm: Ariel litterär kritik, 2014, pp. 65-84: here p. 69 . 


\section{Artistic Research within the Discipline Literary Composition}

The goal of this text is not to write a history of Literary Composition as a discipline. The discipline exists, and, since 2008 , there is also research being conducted within this area. It is this research the text addresses.

Artistic Research was instituted at the University of Gothenburg around the turn of the millennium without the participation of Literary Composition. That Literary Composition did not immediately get on board 'the research train' stemmed from serious doubts concerning what this new discipline could create and house. This initial hesitation within Literary Composition should not be regarded as a simple repudiation of a new practice, as yet another expression of the intellectual historian Sven Eric Liedman's statement, "There will always be those that slam on the brakes and say-this is wrong."2 Not to say yes right away is not the same as saying no. The wheels continued to turn. The door remained open, and this fact was of great importance to the evolution of the alternative (non-)colonisation, which I shall now consider. Liedman states that processes whereby new scientific disciplines are incorporated and accepted as a new component of the ever-larger scientific body historically appear to repeat themselves. He is of the opinion that new scientific disciplines encounter initial and repeated resistance before they are incorporated into the 'academic circle.' I want to assert that Literary Composition did not assume an utterly customary position in this recurring process. The train continued to roll and what became important was instead that the relevant questions were posed, that the right bodies embarked at the right station and at the right time.

Do I always have to write about another world to think about my own world?

In the introduction to her dissertation När Andra skriver (The Writing of Others), the author and poet Mara Lee asserts, "Within artistic research there are thus far quite few methods which can be considered generally valid and divisible." ${ }^{3}$ This truth is perhaps even more relevant if one considers the scholarship produced until now by Literary Composition as a discipline or concentration.

The following may still become an attempt to say something general about a thus far fortunately non-general methodology. A double- or triple-methodology that produced three dissertations by the spring of 2017, which to an exceptional

2 Sven-Eric Liedman, "There will always be those that slam on the brakes and say this is wrong ... ' - On Education and Research in the Humanities and Art," in: ArtMonitor 6 (2009), pp. 149-155: here p. 155 .

3 Mara Lee, När Andra skriver. Skrivande som motstånd, ansvar och tid. Göteborg: Glänta produktion, 2014, p. 26. 
degree are visionary rather than totalising. ${ }^{4}$ Before me, I see a form of conquest that does not conquer something that in itself is silent or silencing, but rather something which speaks and also continues to speak about its subject even after the theoretical-scientific gaze is done glaring. At the same time-on happy occasions - new peals and tones are added to this established speech.

Does the choir always tell the truth?

In the conversation about research within Literary Composition, a possibly underutilised space between education and research has been discussed. Repeatedly, desire was voiced to place the research perhaps surprisingly close to the experience-based conversation and practice long since established as a more or less unspoken pedagogical axiom within Literary Composition. I imagine that a fictional or poetic writing is marked by a simultaneity of feeling and thinking and that this state with perhaps somewhat different emphases is highly relevant also to artistic research. One can speak of 'experience' as another word for 'theory.' And of 'theory' as an ongoing writing practice. Marcia Sá Cavalcante Schuback contends in an essay that in similar "reflective presentations" 5 an "abandonment of aesthetic positions in favor of a self that surrenders to poetic situations" takes place. Situations which, I further imagine, are highly determined by fluctuations and shifts in established seeing.

To look straight into the fire.

\section{Literature and Its Metacritical Gestures}

In the text "Författaren som forskare" ("The Author as Researcher"), the scholar and writer Oscar Hemer writes, "there has never been a lack of self-reflective literature." It is often amusing to assert, for example, that the poem knows more about itself than its author does. And I imagine that the amusing, or attractive, in this statement arises from its partial truth. With the emergence of Literary Composition within artistic research, it becomes possible to 'study' or

4 This text is strictly interested in research conducted within the discipline Literary Composition at the University of Gothenburg. Other artistic research projects concerning literature have been produced in other contexts and within other disciplines; these will not be discussed in this particular text.

5 Marcia Sá Cavalcante Schuback, "Paramgolé - vaghetens poetik," translated by Andreas Gedin and Johan Öberg, in: ArtMonitor 10 (2013), pp. 129-137: here p. 136.

6 Oscar Hemer, "Författaren som forskare - tautologi eller självmotsägelse?," in: Forskning och kritik - granskning och recension av konstnärlig forskning. Stockholm: Vetenskapsrådet Årsbok KfoU, 2010, pp. 101-108: here p. 102. 
consider a situation wherein a linguistic assertion-which in itself contains a more or less manifest metacritical dimension-mingles with yet another meta level. It is then expected (at least in some cases) to originate with the same authorial participation that produced the initial dimension and also (of course) the 'source text' itself. That construction warrants close consideration. It creates a specific situation that should reasonably affect the emergence of scientific discourse.

Irhyme in order to know what I do not already know.

So what is meant by this inherently textual reflexive dimension which arguably should be relevant to the space where artistic research about and around artistic writing operates? The question is too broad to grapple with, and for that reason it is, I imagine, better to become concrete by very briefly discussing a set of different but linked examples.

There is a poem by the Swedish poet and literary scholar Gunnar D. Hansson titled "Långröse" ("Long Cairn Grave") that can be found in the book Förlusten av Norge (The Loss of Norway). A "long cairn grave" is a pre-historical grave consisting of rocks gathered in a formation whose length is at least twice its width. In the poem's two mottos we learn more about the nature of a "long cairn grave." In the first one, G. A. Gustafson writes, "Most are now disturbed so that they make a bumpy, low ridge, with somewhat irregular sides and ends." ${ }^{7}$ Hansson's poem does not become more explicit about the nature of "long cairn graves," nor can the term itself be found anywhere but in the poem's title. However, the poem visually (and studiously) describes a "long cairn grave." The short, centred lines sketch out an iconic image: a long and narrow, approximately four pages long, reflective surface with "irregular sides," where the title and influences which arise in my reading can be amplified, broken against each other and thereby deepened. "Långröse" is a poem about death. And about "long-term successes." It mentions "the final point" and "night of death." Before the poem was published in Förlusten av Norge, it could be read in the publication Ord \& Bild in 1998. When the poem was written, Gunnar D. Hansson, born 1945, was most likely around fifty years old. Early in the poem, I read, "Fröding9 became / fifty-one (almost). / Shakespeare became fifty-one (slightly more than)."10 The list soon grows longer when Honoré de Balzac, Rainer Maria Rilke and Marcel Proust join the group of those who died around the age of fifty-one. In "Långröse"

\footnotetext{
7 Gunnar D. Hansson, Förlusten av Norge. Stockholm: Albert Bonniers Förlag, 2000, p. 165.

8 Hansson (2000), Förlusten av Norge, pp. 167-168.

9 Gustaf Fröding, prominent Swedish poet and writer (1860-1911).

10 Hansson (2000), Förlusten av Norge, p. 167.
} 
and Hansson's expansive and often conspicuously self-conscious writing, I think there are many meta-levels. What I want to emphasise here is guided by a visual, iconic instance. With its visual appearance but also with the thinking about the end that can arise once one has turned 51 years old, it can evoke a kind of terror, as if one stands before a pagan burial ground. As a reader one feels amazed and slightly redundant or helpless.

NOW THE NOUNS BECOME EXTINCT.

There is another-different but similar-example from the poet Ann Jäderlund's book I en cylinder $i$ vattnet av vattengrät (In a Cylinder in the Water of Waterweeping) from 2006. A short poem reads (and looks) as follows:

$$
\begin{aligned}
& \text { I can } \\
& \text { Not } \\
& \text { lock } \\
& \text { My self in } \\
& \text { the light in } \\
& \text { the room under } \\
& \text { the footsteps } \\
& \text { the soles / the round } \\
& \text { foot's soul }
\end{aligned}
$$

The initial statement "I can / not / lock / Myself in" is interesting, since all words save for 'not' and 'in' are widened, that is to say, the characters are kerned to be set wide apart. ${ }^{12}$ The assertion might appear illogical, even incorrect; and as a way of addressing this the non-widened word 'not' becomes critical since it makes the negation's abrogating function wobble. If one removed the word 'not' entirely, the clause would collapse in a logically obvious manner. However, one cannot treat a poem in any way. At the same time, further questions arise: Is the 'I' of the poem jailed or not jailed in the light and the room? Also the words 'not,' 'lock,' and 'footsteps' are each placed on their own lines so that they attract additional attention. Finally, the ambivalence between the open and the closed that runs throughout the nine lines is not resolved. Rather, the poem deploys this vacillation. The metacritical statement produced by the poem's

11 Ann Jäderlund, I en cylinder $i$ vattnet av vattengråt. Stockholm: Albert Bonniers Förlag, 2006, p. 48.

12 In Swedish, the word "spärra" signifies both "lock" and "widen," i.e. being "locked in" or "stopped," but also a widened, or typographically kerned text. The poem engages with this double meaning. 
typographical and semantic work actualises what Roman Jakobson once described as an "ambiguity" which is "a corollary feature of poetry." Jakobson cites William Empson, "The machinations of ambiguity are among the very roots of poetry."13 A vital insight for considering Jäderlund's poem concerning the significance of the poetic ambivalence, in this case revealed in and through the poem's visual iconicity.

In Jäderlund's poem — as in "Långröse" above — the interplay between semantics and iconicity enhances the poems' modes of being and speaking selfreflexively. Despite their possibly epistemological goals, the two examples are not to be regarded as artistic research. They consider themselves in the way in which poetry and literature have always considered themselves. And that is a quality that the artistic researcher in their scholarly practice must not forget.

The ground is ploughed through.

The kinds of readings that capture the literary text's metacritical gestures are possible within a scholarly literary discourse. But the charge of artistic research is in part another one. Here, the arrangement demands that an author, in writing, comments upon and analyses a text they have written beforehand, and that can appear difficult. The comment runs the risk of destroying a practice, or a literary text. Or, in the best case, it will merely appear uninteresting or 'primitive' compared to the literary text's exposition about itself. ${ }^{14}$ This means that the artistic research concerning Literary Composition must occupy the research space in other ways. The conquest must be different, and the furnishing of the space must never be completed. One way of addressing this might be to say that artistic research within Literary Composition to a higher degree should take place through rather than about literary writing. Or about a literary writing in which a through occupies a prominent place.

The sawing of language is ongoing.

13 Jakobson, Roman, “Closing Statement: Linguistics and Poetics," in: Thomas A. Sebeok, ed., Style in Language. Boston, MA: The Technology Press of MIT and New York, NY, London: Wiley, 1960, pp. 350-377: here p. 371.

14 Staffan Söderblom writes: "[T] he separating meta-level, or self-reflection, would [risk] appearing primitive, even irrelevant, in comparison to what is inscribed in the literary work's own structure." Staffan Söderblom, "Anteckningar om senfärdighet - om ansatsen till konstnärlig forskning inom det litterära området," in: Konst och forskningspolitik - konstnärlig forskning inför framtiden. Stockholm: Vetenskapsrådet Årsbok KfoU, 2009, pp. 61-74: here p. 64 . 


\section{Artistic Writing as Artistic Research. Artistic Research as Artistic Writing}

Despite limitations in the empirical material, I do not think I am only engaged in speculation when I assert that artistic research in Sweden was partially transformed when writing and literature entered the field. The inquiries of artistic research concern an artistic doing, a practice, and the scope of the discipline is necessarily impacted when this very doing is manifest as text. When the linguistic and textually evident gesture is commented upon in a similar linguistic, textual gesture something happens with what one very sloppily tends to term critique. The critique or reflection settles so close to what it reflects upon that the two can be difficult to parse. This conflating movement is further enhanced by the establishment of the metacritical parameters I above asserted as palpable and inherent to the literary work.

Now I want to sing softer and deeper.

In her reflections, "On Methods of Artistic Research," Annette Arlander wonders if not "each artform" should develop "its own scientific methods based on the common working methods" within the practice in question..$^{15}$ One can easily agree with that, I imagine. However, even within one specific artform, a general method can be difficult to establish and maintain. The quantitatively limited research produced thus far in Literary Composition at the University of Gothenburg may indicate that the author does not firstly explore others' work but to a higher degree conducts research through or with the help of the specific practice which also produced the primary work/text. The research bodies at Literary Composition have therefore not been part of a process wherein the author at a certain point-during or upon the completion of a particular project-ceases to be an author and is transformed into a researcher. I think (and in some cases know) that the specific author-researcher body has instead strived to create a second form of artistic text, artistic acoustics, in a gesture that at the same time includes a reflection through or via this text, this acoustics.

Perhaps I am talking about the chicken and the egg. But I am also talking about writing as a thinking practice and about an expansion with several different faces. Susan Howe writes about how her long-standing presence of lyrical language has created a specific thought structure, "a habit of thinking

\footnotetext{
15 Annette Arlander, "On Methods of Artistic Research," in: Method - Process - Reporting. Stockholm: Swedish Research Council Yearbook KfoU, 2014, pp. 26-39: here p. 28.
} 
within patterns of rhythmic phrasing." ${ }^{16}$ This figuration is relevant to what has been produced, relevant to both the chicken and the egg.

Ideas do not generate poetry.

There is a notion - a 'ghost image' - about artistic research and the artistic researcher, where an interpretive or critical dimension is placed up against (above, next to, below) the work that the artist/researcher has produced. This notion has gained much of its vitality from the fact that this is what artistic research has sometimes looked like. And it has occasionally on vague grounds been described as such. This research position becomes problematic if it beins, in an active way, to haunt the literary text and all its multivalent and metacritical statements. The researching authorial body must place itself somewhere else in the research space, and do something else within that realm. ${ }^{17}$ In the following, I will summarise and briefly discuss the three dissertation projects completed in Literary Composition until May 2017. Ghosts exists. But one can keep them at a distance in various ways.

Poetry sometimes generates ideas.

Early on in Mara Lee's dissertation När Andra skriver, one can read that the dissertation at hand will "do theory." She wants to create tools that do not merely describe Other bodies' positions but also in themselves become "concrete practices of resistance."18 Also, Lee is initially clear in her insistence upon the significance of the practice of writing to and within the project. In one of the "entry points" and under the rubric of "The Question at Hand," Lee writes,

The Writing of Others: Writing as Resistance, Responsibility and Time is a book that is based in literary practice. It deals with the experience of writing out of another body, and wants to show how this experience is intimately bound up with different temporalities that disrupt and interrogate our linear conception of time. ${ }^{19}$

To write poetry is a doing - the Greek poiesis means 'to do' - and to break the line, as in the lyric verse, can be seen as emblematic of this dimension of doing

16 The paragraph is quoted from Peter Middleton, "The Contemporary Poetry Reading," in: Charles Bernstein, ed., Close Listening. Poetry and the Performed Word. New York, NY: Oxford University Press, 1998, pp. 262-299: here p. 273.

17 Magnus Bärtås, "Verkberättelse som pilgrimage," in: ArtMonitor 10 (2013), pp. 11-23: here p. 15 .

18 Lee (2014), När Andra skriver, p. 13.

19 Ibid. 
in poetry. Accordingly, lyrical passages constitute a significant element of Lee's dissertation. Another device is "temporal figurations" of Otherness that are named and brought into being. They are called "revans moments," "the eleventh hour," and "stemmed time." 20 With the aid of these characters-among other things - the othering becomes procedural, and the reader gains a partially new perspective on an established problem. The same happens in the chapter "Displacements 1. Language Is Our Home, a Home in Motion" where Lee examines and reveals ideologies which, like small doses of arsenic, have permeated and poisoned language itself. Why is 'barnhem' - literally, 'child home' in Swedish - called barnhem when it is so obviously not a home. The Swedish idea of 'folkhemmet' ('the people's home') ${ }^{21}$ was, among other things, an attempt to bridge differences, and one step in this process involved the fact that we should all always be at home, "no matter how far away we are."22

The forest game is a writing game.

Helga Krook's dissertation Minnesrörelser (Movements of Memory) consists of six separate volumes with six different senders of whom one is named Helga Krook. The 9o-page pamphlet bearing Helga Krook's signature is in one place described as a "coat for a body" and soon after that as an epilogue, while it in another place states that there is no "given order in which the books should be read." ${ }^{23}$ Hilde Lindroth, Elisa Adrian, Linda Beel, Grete Wiedrow, and Anja Nauchaum are the translators, editors, cultural journalists, critics, and poets who, together with the "closed-down author" Helga Krook, read, write, andin another turn yet again — read the material gathered by Helga Krook. The construction of the dissertation aims, writes Krook, to "reach something more complex than what I could have if I had written the dissertation myself." ${ }^{24} \mathrm{I}$ imagine that the construction also aims to stage the critical assertion to be found on page 36 of the Helga Krook volume: "Language contains a history." Different languages from different senders contain different histories.

The research subject Helga Krook asserts that she does not regard "a dissertation in Literary Composition" as a test of knowledge. In line with this idea, she develops a clearly readable movement away from one truth-seeking

20 Lee (2014), När Andra skriver, p. 16.

21 Also known as 'the Swedish Middle Way,' a political concept central to the development of both the Swedish welfare state and Swedish Social Democratic Party, wherein the nation is conceived of as a small family, and everyone contributes.

22 Lee (2014), När Andra skriver, p. 156.

23 Helga Krook, "Berätta för mig II," in: Minnesrörelser. Göteborg: Autor, 2015, pp. 17-82: here pp. 26 and 59 .

24 Krook (2015), Berätta för mig II, p. 13. 
interpretation of the gathered material's own claims to an important and problematising discussion about memory and the very conditions for knowledgetransfer. She states, "The project Movements of Memory can be regarded as a representation of a narrative problem examined within disparate practices."25 And such a centrifugal movement assumes the consequences of the view of the collected-and for us, non-existent-materials as in themselves an expression of various treatments and distortions.

No choir can be seen coming through the forest.

My dissertation Hur later dikten? Att bli ved II (What is the Sound of the Poem? Becoming Firewood II), takes up how different acoustic dimensions can appear in and be realised through poetry. It consists of a relatively extensive volume that also includes a $\mathrm{CD}$ with five text-sound compositions I participated in producing. At the opening I state, "As part of the dissertation, there is also the poetry collection Becoming Firewood," published by Norstedts förlag in conjunction with the completion of the dissertation. ${ }^{26}$ If one begins to page through and read the dissertation, one will quite soon notice that it contains a range of writing practices or writing attempts and that this disparate collection of materials is, I would assert, conscious - perhaps even methodical—strategy on my part. In the creation of this montage - aided by what the poet Magnus William-Olsson in one place terms "the oscillating attention"-imminent dichotomous hierarchies between, for example, representative and non-representative, between work and critique, between theory and practice can be partially set aside. ${ }^{27} \mathrm{To}$ seek out, test, and realise different writing practices became the approach that guided and set conditions for the exploration, as well as what is not unproblematically termed the production of knowledge. Johan Öberg has stated, "In truth, artistic research is not concerned with the production of knowledge as much as it is in laying claim to knowledge." 28 I think this is important, in the same way that it is crucial to continuously assert that poetry is not concerned with production but with processes. With an expansion that, when successful, time and again can surprise the reader. Helga Krook writes in accordance with this about the importance of "refusing to deliver."29

I dig to know what I do not already know.

25 Krook (2015), Berätta för mig II, p. 12.

26 See colophon Fredrik Nyberg, Hur låter dikten? Att bli ved II. Göteborg: Autor, 2013.

27 Magnus William-Olsson, "Denna oroligt uppmärksamma ensam-med-mig-själv-polka i mörkret," in: Magnus William-Olsson, ed., Methodos. Konstens kunskap, kunskapens konst. Stockholm: Ariel litterär kritik, 2014, pp. 9-35: here p. 34.

28 Johan Öberg is cited in: "Magnus Bärtås - samtal," in: ArtMonitor 10 (2013), pp. 24-31: here p. 28.

$29 \operatorname{Krook}(2015)$, Berätta för mig II, p. 72. 


\section{Conclusion}

Just like the body of language constituted by Minnesrörelser, neither do the three dissertations discussed here constitute one gathered body, one shared code. However, I do think that the three works share a desire within the writing subject to, at no point during the research practice, cease to be the author. There is a will to continue to be specific.

As a consequence, the researching author in these three dissertations is not an author as researcher "in their own profession" but an author who researches through the various forms of writing, language, and strategy available to them. ${ }^{30}$ It is a researcher who arises from and acts within and through the questions that emanate from the ongoing writing practice. It is about flexible relationships, about changes rather than positions. The dissertation as a whole becomes an important attempt to not continuously construct or write 'the same history,' the same discourse. It is essential and at the same time very difficult to challenge oneself. And what this challenging act looks like can be highly individualised. I imagine that these dissertations and also future ones at Literary Composition can be a way to challenge what is the established way of writing and being and thinking in the author's body.

The Hölderlin music is strange.

Translation from Swedish by Jennifer Hayashida.

\section{Bibliography}

“Magnus Bärtås - samtal," in: ArtMonitor 10 (2013), pp. 24-31.

Arlander, Annette, "On Methods of Artistic Research," in:Method - Process - Reporting.

Stockholm: Swedish Research Council Yearbook KfoU, 2014, pp. 26-39.

Bärtås, Magnus, "Verkberättelse som pilgrimage," in: ArtMonitor 10 (2013), pp. 11-23.

Hansson, Gunnar D., Förlusten av Norge. Stockholm: Albert Bonniers Förlag, 2000.

Hemer, Oscar, “Författaren som forskare - tautologi eller självmotsägelse?", in: Forskning och kritik - granskning och recension av konstnärlig forskning. Stockholm: Vetenskapsrådet Årsbok KfoU, 2010, pp. 101-108.

Hjertström Lappalainen, Jonna, "Att reflektera över det som ännu inte sagts," in: Magnus William-Olsson, ed., Methodos. Konstens kunskap, kunskapens konst. Stockholm: Ariel litterär kritik, 2014, pp. 65-84.

Hemer (2010), Författaren som forskare, p. 102. 
Jakobson, Roman, “Closing Statement: Linguistics and Poetics," in: Thomas A. Sebeok, ed., Style in Language, Boston, MA: The Technology Press of MIT and New York, NY, London: Wiley, 196o, pp. 350-377.

Jäderlund, Ann, I en cylinder i vattnet av vattengråt. Stockholm: Albert Bonniers Förlag, 2006.

Krook, Helga, "Berätta för mig II," in: Minnesrörelser. Göteborg: Autor, 2015.

Lee, Mara, När Andra skriver. Skrivande som motstånd, ansvar och tid. Göteborg: Glänta produktion, 2014.

Liedman, Sven-Eric, "There will always be those that slam on the brakes and say this is wrong...' - On Education and Research in the Humanities and Art," in: ArtMonitor 6 (2009), pp. 149-155.

Middleton, Peter, “The Contemporary Poetry Reading," in: Charles Bernstein, ed., Close Listening. Poetry and the Performed Word. New York, NY: Oxford University Press, 1998, pp. 262-299.

Nyberg, Fredrik, Hur låter dikten? Att bli ved II. Göteborg: Autor, 2013.

Schuback, Marcia Sá Cavalcante, "Paramgolé - vaghetens poetic," translated by Andreas Gedin and Johan Öberg, in: ArtMonitor 10 (2013), pp. 129-137.

Söderblom, Staffan, "Anteckningar om senfärdighet - om ansatsen till konstnärlig forskning inom det litterära området," in: Konst och forskningspolitik - konstnärlig forskning inför framtiden. Stockholm: Vetenskapsrådet Årsbok KfoU, 2009, pp. 61-74.

William-Olsson, Magnus, "Denna oroligt uppmärksamma ensam-med-mig-själv-polka i mörkret," in: Magnus William-Olsson, ed., Methodos. Konstens kunskap, kunskapens konst, Stockholm: Ariel litterär kritik, 2014, pp. 9-35. 